\title{
Sztuka jako uobecnianie
}

Jeśli kiedyś wydawać się mogło, że sztuka jest odwzorowaniem świata lub może inaczej - jest jego kreacją, to kto wie, czy dzisiaj nie dałoby się zobaczyć jej z perspektywy, która dramatyzuje mimesis, czyniąc to pojęcie kategorią relacyjną i procesualną.

Sztuka, jakby powiedział Richard Shusterman, jest dramatyzacją, która, dodajmy, odnosi się nie tylko do gry, ale jest nieustanną próbą powoływania świata na scenę. Świat zostaje zaproszony do teatru sztuki już nie tylko po to, aby się przedstawił, schylił w pokornym ukłonie przed publicznością lub hardo rzucił jej wyzwanie, zmuszając do akceptowania swych reguł, ale by dawał się pokazywać stale w kolejnych odsłonach - zawsze inaczej, w zmiennym, migotliwym świetle reflektorów, w barwach lub szarościach, w ostrych konturach lub miękkich kształtach. Nie wydaje się więc paradoksem, że świat uobecnia się w sztuce i sztuka powoduje uobecnienie świata.

Każde działanie artystyczne ma charakter epistemologiczny; bez doświadczenia sztuki nie byłoby świadomości poznania. Kategoria uobecniania celowo nawiązuje do neologizmu nieobecnienie, który został użyty $\mathrm{w}$ tytule jednego z publikowanych $\mathrm{w}$ tym numerze artykułów, dotyczącego próby opisania doświadczenia śmierci. Oba określenia wskazują na procesualność jako istotę samej obecności, mówią wręcz o jej stopniowalności, a nawet podkreślają aspekt niedokonany wydarzania się w czasie. Dzięki nim obecność uzyskuje nowe przymioty; trwa zawieszona między zjawianiem się a zanikaniem.

Uobecnianie w sztuce nie jest równoznaczne z samą obecnością, ale odwołuje się do inicjowania procesu zachodzącego między intensyfikacją form bytów niepełnych, niejasnych, odbitych, wszelkich Leśmianowskich „niedoistnień” i „niedowcieleń”, wytężających swe siły w walce o prawa do uzyskania wszystkich atrybutów istnienia, lub inaczej, mówiąc słowami Przybosia, chcących „swoje oblicze do jawy natężyć” a zanikaniem, stawaniem się nieobecnością, wspomnieniem, wyznaczanym miejscem nieistnienia, jakim jest na przykład akt „wymazywania” Bernharda czy Rauschenberga, „spopielania” Becketta czy Kifera.

W sztuce nic nie dzieje się bezkarnie - byt powołany niszczeje i zamiera, byt przekreślony zachowuje pamięć pierwszego oblicza, ulega powtórnemu scaleniu. Sztuka jest ciągłym procesem uobecniania, czyli powoływania do kształtu i trwania, przy równoczesnym wyznaczaniu miejsca zaniku i nieobecności. Pojęcia pozytywne, waloryzowane dodat- 
nio, zmaterializowane, powołane na scenę nigdy już nie będą osobne od ich cieni, przenicowanych materii, drugich stron, podszewek, spodów. Obecności towarzyszy świadomość utraty, brakowi - pamięć śladu, blaknięciu intensywność barwy.

Widzimy scenę wypełnioną bytami hybrydowymi, człowiek sprzężony z maszyną, roślina wyłaniająca kształty zwierzęce, robot z ludzką twarzą, istota ludzko-zwierzęca, kobieta kot, mężczyzna wilk. Metamorfozy antyczne, mimo że miały nieco inny charakter, przypominają często współczesny świat sztuki uobecniania. Przejścia, wcielenia, przemiany zawsze były wyrazem niepewności ontologicznej. Półbogowie, półludzie, centaury, syreny, minotaury, nimfy i wszystkie inne postacie mitologiczne przypominały o braku stabilizacji naszych wyobrażeń związanych ze stałymi granicami bytów. Sztuka rozchwiała poczucie stabilnej, jednoznacznej pewności, ale też $\mathrm{w}$ zamian dała nieograniczone możliwości uobecniania. Dziś w takich ujęciach pomaga świadomość performatywna, czyli taka, która potrafi powołać miejsce puste jako ślad bytu, stwarza dyskurs, którego wcześniej w dziełach nie było. Płynną możliwość przejść między sposobem widzenia i doświadczania bytu w sztuce daja także media, na gruncie których możliwa jest zamiana tradycyjnego wizerunku postaci na zapis cyfrowy. Cielesność podważa sama swój status (por. tradycyjny performance jako doświadczenie fizycznego ciała i praca $\mathrm{z}$ systemem kamer przemieniających realne ciało w powielane układy sekwencji obrazów, niekiedy odrealnionych, multiplikowanych, zastąpionych obrazem graficznych układów itp.). Stąd zjawiska literackie często uzyskuja nowe kategorie interpretacyjne, jak rzeczywistość wirtualna, hologram, światy możliwe, równoległe. Antykartezjański dramat sztuki rozwija się w siatce wzajemnych powiązań i odniesień pojęć antybinarnych, jak powtórzenie, chiazm, synestezja, chronotop, oksymoron. Powszechna stała się myśl o łatwości zmiany stanów materii, która okazać się może za chwilę popiołem lub opisana zostać przez model falowy. Czy w takim porządku zmienności świata jest jeszcze miejsce na śmierć? Chyba tylko już może zachodzić proces nieuobecnienia. Dlatego pewnie w sztukach Samuela Becketta nie wyznaczono roli dla śmierci, która nie przychodzi spoza sceny, nie porywa jak w tańcach śmierci do wspólnego pląsu, lecz istnieje stale, jest istotą rzeczy, trwa w niszczejących niczym przedmioty kalekich postaciach, pojawia się teraz, a może już w innym miejscu.

Wydaje się, że sztuka jest zaprzeczeniem śmierci - sztuka powoduje stałe uobecnianie istnienia, podczas gdy domeną śmierci jest dokonanie gestu jego nieuobecnienia. Powiedzenie Ars longa vita brevis nabiera dziś jeszcze innego odcienia interpretacji, zakładając, że sztuka nie- 
ustannego uobecniania pokonała ideę śmierci jako ostatecznego końca, powiedzieć by można, że jej czynność jest niedokonana, trwa w każdej chwili i paradoksalnie nie pokonuje żadnej. Proces nieuobecniania każdorazowo zaciera granice istnienia jedynie jednej z jego formuł, sztuka, uobecniając ich wielość, daje szansę stałego powoływania nowych kształtów, pokazania pełnych metamorfoz. Obie są dramatyczne, jeśli rozumieć dramat, jak chciał Deleuze, nowocześnie i poheglowsko, jako ruch. Zarówno śmierć, jak i sztuka są domenami tego samego procesu igrania ze stabilnością bytu i przekreślania antropocentrycznej koncepcji człowieka. Sztuka i śmierć od wieków splatają się w figurach tego samego tańca, walcząc o prowadzenie w określaniu sensu utrwalenia błysku chwili i zatrzymania ulotnej postaci egzystencji. Toczy się ustawiczna gra między powołaniem do istnienia a jego zanikiem, między nabieraniem intensywności koloru a wtopieniem się niknącej barwy $\mathrm{w}$ tło obrazu.

Anna Krajewska 